\title{
Reproductive disorders affecting 21-month-old bulls assessed by andrological examination
}

\section{Afecções reprodutivas que acometem tourinhos (21 meses) avaliados por meio de exame andrológico}

\author{
Ana Paula Luiz de Oliveira ${ }^{1}$; Adalfredo Rocha Lobo Júnior ${ }^{2}$; Erick Fonseca de \\ Castilho $^{3}$; José Domingos Guimarães ${ }^{4}$; Thiago Vasconcelos Melo²; Diego Azevedo \\ $\operatorname{Mota}^{2}$; Jeanne Broch Siqueira ${ }^{2 *}$
}

\section{Highlights:}

Higher prevalence of testicular pathologies in Nelore bulls.

High incidence of vesicular alterations in confined young bulls.

Penile adhesion ratio in young bulls.

\begin{abstract}
The objective of this study was to identify the prevalence of the main pathologies that affect the genital organs of young bulls. We used a database that contained data for 6,408 young Nelore bulls. The data were collected from June to August 2004 and 2005. The bulls were evaluated by andrological examination and semen samples were collected with the aid of an electroejaculation device. The animals were classified in terms of their sexual maturity as animals suitable for reproduction, animals suitable for reproduction in terms of natural service, animals temporarily unfit for reproduction, and animals excluded from reproduction. The reproductive disorders recorded in the excluded animals were classified as penile, testicular, anterior or posterior limb, epididymal, spermatic cord, spermatic, anal sphincter, foreskin, systemic, and seminal vesicle alterations. We used descriptive statistics and analysis of variance to analyze the data. Of the 6,408 bulls evaluated, 309 animals were excluded from reproduction (4.82\%). The majority of the excluded bulls (31.7\%) suffered from testicular-related pathologies (testicular asymmetry, small scrotal circumference for their age, orchitis, and hydrocele $(64.28 \%, 32.65 \%, 2.04 \%$, and $1.02 \%$, respectively), seminal vesicle alterations $(31.39 \%)$, sperm defects $(17.15 \%)$, and penile alterations $(6.79 \%)$. Of the 309 animals excluded from reproduction, $21(6.79 \%$ of the excluded and $0.32 \%$ of the total animals) suffered from some type of penile alteration, such as persistence of the frenulum (16/21) and total or partial penile adhesion $(5 / 21)$. Confining the herd for two months and subjecting the animals to their first andrological examination at a younger than usual age, with the objective of selling them, could be why there were high incidences of seminal vesicle pathologies (owing to the homosexual behavior of the males) and of penises with high adhesion rates, which are characteristic of animals that have not yet entered puberty. In general, the low percentage of animals excluded from reproduction in the studied herd indicates the adequacy of the selection program. Key words: Bovines. Reproduction. Pathologies.
\end{abstract}

\footnotetext{
${ }^{1}$ Médica Veterinária Residente, Programa de Residência em Área Profissional da Saúde, Medicina Veterinária e Saúde, Faculdade de Ciências Agrárias e Veterinárias, Universidade Estadual Paulista, FCAV/UNESP, Câmpus de Jaboticabal, Subárea Reprodução Animal e Obstetrícia, Jaboticabal, SP, Brasil. E-mail: anapaulaluizdeoliveira@gmail.com

2 Profs. Drs., Universidade Federal dos Vales do Jequitinhonha e Mucuri, UFVJM, Instituto de Ciências Agrárias, Unaí, MG, Brasil. E-mail: adalfredo.lobo@ufvjm.edu.br; diego.mota@ufvjm.edu.br; thiagovmelo@gmail.com; jeanne.siqueira@ufvjm.edu.br

3 Prof. Dr., Universidade Federal Rural da Amazônia, UFRA, Instituto da Saúde e Produção Animal, Belém, PA, Brasil. E-mail: efcmv@yahoo.com.br

4 Prof. Dr., Universidade Federal de Viçosa, UFV, Viçosa, MG, Brasil. E-mail: jdguima@gmail.com

"Author for correspondence
} 


\section{Resumo}

Objetivou-se identificar a prevalência das principais patologias que acometem os órgãos genitais de tourinhos jovens. Foi utilizado um banco de dados de 6408 touros jovens da raça Nelore, nos meses de junho a agosto de 2004 e 2005. Os tourinhos foram avaliados por meio de exame andrológico e o sêmen coletado com auxílio do eletroejaculador. A maturidade sexual dos animais foi classificada em: animais aptos à reprodução, animais aptos à reprodução em regime de monta natural, animais temporariamente inaptos à reprodução e animais descartados. As afecções reprodutivas registradas nos animais descartados foram distribuídas em: alterações de pênis, testículos, membros anteriores ou posteriores, epidídimo, cordão espermático, alterações espermáticas, alterações do esfíncter anal, prepúcio, sistêmicas e de vesícula seminal. Análises descritiva e de Variância foram realizadas para análise dos dados. Dos 6408 touros avaliados, 309 animais foram descartados da reprodução $(4,82 \%)$. A maioria dos touros descartados $(31,7 \%)$ apresentou patologias relacionadas ao testículo (assimetria testicular, baixo perímetro escrotal para a idade, orquite e hidrocele, com valores de 64,28, 32,65, 2,04 e $1,02 \%$, respectivamente), e vesículas seminais ( $31,39 \%)$, seguidas pelos defeitos espermáticos $(17,15 \%$ dos descartados) e alterações de pênis (6,79\%). Dos 309 animais descartados da reprodução, 21 (6,79\% dos descartados e $0,32 \%$ do total de animais) apresentaram algum tipo de alteração peniana como persistência do frênulo (16/21) e aderências penianas, total ou parcial (5/21). O confinamento do rebanho por dois meses e a redução da idade dos animais para realização do primeiro exame andrológico, com objetivo de venda de animais precoces, podem ser os responsáveis pela maior incidência de patologias relacionadas às vesículas seminais (devido ao comportamento de sodomia dos machos) e pênis com alta incidência de aderências, característicos de animais que ainda não entraram na puberdade. De maneira geral, a baixa porcentagem de animais descartados da reprodução no rebanho estudado, indica adequado programa de seleção.

Palavras-chave: Bovinos. Reprodução. Patologias.

\section{Introduction}

The basis of selecting cattle for a herd and improving it genetically starts by selecting a good sire. Sire selection within this context guarantees an increase in the herd's productivity both quantitatively (number of animals) and qualitatively (genetic improvement) (Ohashi et al., 2018).

A bull's reproductive fitness assessment is based on the absence of extragenital diseases that may interfere with his overall condition or ability to copulate, the absence of hereditary defects that may be evident from the animal's phenotype, and the absence of genital infections as well as on the fecundating capacity of his semen (Krause, 1993). Thus, knowledge of the seminal characteristics as well as the internal and external genital organ anatomy of bulls observed by andrological examination may set the foundations for more appropriate guidelines regarding the selection of the most appropriate bulls in terms of fertility and their treatment in commercial herds.

Alterations to the bull's genitals, whether they are genetic or caused by the environment, an infection, or an injury, can result in subfertility, infertility, or sterility. Although subfertile bulls can produce offspring, subfertility is an undesirable trait, especially when it is genetic in nature, as it is transmitted to the next generations. Therefore, in order to obtain a definitive diagnosis and prognosis of subfertility, it is advisable to examine a bull carefully and to analyze different ejaculate samples obtained at different time points (Vale, Pinto, Fonseca, \& Soares, 1979).

In Brazil, Vale et al. (1979) were among the pioneers who aimed to elucidate the causes, origin, and forms of subfertility and infertility in the bovine male, as well as to establish the prevalence of the problems by conducting a study on 1,088 zebuine, 
taurine, or mixed-breed bulls in the country. In this study, the main causes of low fertility or infertility in bulls, regardless of their genetic constitution, were testicular degeneration, delayed sexual maturity, testicular hypoplasia, imperfect spermiogenesis, and sexual immaturity. According to the authors, all the clinical cases resulted from unfavorable environmental conditions and poor husbandry practices. These results evidence that the fertility of sires in Central Brazil has left a lot to be desired, thereby indicating the need for the adoption of better genotypic selection criteria and better, overall, management practices, while also emphasizing the need for careful clinical, sanitary, and andrological examinations of the sires.

The objective of the present study was to identify and describe the main pathologies affecting the external and internal genitalia of young bulls, which were excluded from reproduction after being evaluated via andrological examination in a herd improvement program.

\section{Materials and Methods}

The database that we used contained data for 6,408 young Nelore bulls, which were evaluated by andrological examinations. The data were collected from June to August 2004 and 2005 and the herd was owned by Agro-Pecuária CFM Ltda. The animals were raised on pasture, predominantly on Brachiaria decumbens grass (40\%) and Guinea grass (Panicum maximum; 50\%), with ad libitum access to mineral salt and water.

The herd used was subjected to a genetic improvement program. One of the parameters measured in the implemented model was the scrotal circumference (SP). In addition, the herd participated in a program promoted by the Ministry of Agriculture, Livestock, and Food Supply (MAPA), for which it received a Special Certificate of Identification and Production (CEIPs), where only $30 \%$ of the males produced could be marketed as breeding stock. Thus, in the present study, only bulls ranked in the top $30 \%$ according to the herd improvement program and with commercial potential were evaluated.

After the animals were placed in individual squeeze chutes, we measured several testicular characteristics, which included testicular length and width and SP; additionally, we classified the testes based on their consistency. The testicular length and width measurements were obtained with the aid of a pachymeter; the length was measured according to the longest side of the gonad (dorsum-ventral), which included the head and excluded the tail of the epididymis, and the width was measured in the widest region of the gonad, in the lateral-medial direction, using the animal's body as reference. The SP at the time of the andrological examination was obtained with the aid of a measuring tape, after slight ventral-caudal traction of the gonads and in the widest region of the scrotum. As this was an animal breeding program, all animals that had an $\mathrm{SP} \leq 26 \mathrm{~cm}$, were excluded from reproduction. The testicular consistency was assessed by palpating both testicles along their entire length; then, these were classified as either tense, tense elastic, slightly flaccid, or flaccid.

We used the electroejaculation method to obtain ejaculates. After collecting the ejaculates, their physical characteristics were examined. We evaluated the wave motion (mass sperm motility) on a scale from 1 to 5 , with the aid of conventional microscopy at a $200 \times$ magnification, by placing $10 \mu \mathrm{L}$ of the semen sample on a slide, previously heated to $37{ }^{\circ} \mathrm{C}$. Subsequently, we placed another $10-\mu \mathrm{L}$ semen aliquot between the slide and the coverslip, previously heated to $37^{\circ} \mathrm{C}$, and evaluated the sperm motility $(0-100 \%)$ and sperm vigor $(0-5)$ using a phase contrast microscope (BX40 Olympus, Melville, New York, U.S.A) at a 200-400× magnification.

For the morphological analysis of the sperm, we packed and stored a semen sample (sufficient to cloud the solution) in $1 \mathrm{~mL}$ of buffered saline 
formalin (Hancoch, 1956). For this evaluation we adopted the methodology recommended by Blom (1973, 1983), by logging the head, tail, and acrosome defects and classifying the anomalies into major, minor, and total sperm defects. Four hundred sperm cells per ejaculate were analyzed, with the aid of phase contrast microscopy, at a $1,250 \times$ magnification.

The sexual maturity was classified according to the study of Guimarães (1997) on the spermatogenesis, physiopathology of reproduction, and physical and morphological characteristics of the sperm as follows: 1: sexually mature, suitable for reproduction animals, according to the standards recommended by the Colégio Brasileiro de Reprodução Animal [CBRA] (2013); 2: sexually mature animals, with sperm pathology rates that did not compromise the fecundating capacity of the ejaculate, therefore classified as fit to reproduce in a natural manner; 3: animals that were sexually immature and temporarily unfit for reproduction; 4 : excluded animals.

The animals classified as excluded were distributed in 10 categories depending on the alteration characteristic (reproductive or not) responsible for excluding the animal from reproduction. These categories were: 1: penile alterations (partial or total adhesion and persistence of the frenulum); 2: testicular alterations (testicular asymmetry, hydrocele, orchitis, and small SP for the animal's age); 3: anterior or posterior limb alterations (hoof lesions, limb lesions, hygroma, alignment defects, and fractures); 4: epididymal alterations (epididymal tail fibrosis and segmental aplasia); 5: spermatic cord changes (shortening of the spermatic cord and testicular torsion); 6 : spermatic changes (imperfect spermiogenesis and acrosome defects); 7: anal sphincter changes (anal sphincter stenosis); 8: foreskin changes (stenosis of the preputial ostium and phimosis); 9: systemic changes (fibropapilloma); 10: seminal vesicle changes (uni- or bilateral vesiculitis).
Initially, we used descriptive statistics to evaluate the data trends. Then, we performed analysis of variance (ANOVA) on all variables using a mixed model, in which the fixed effects of group, year, and their interactions were considered. Moreover, the age of the animals was used as a covariate in the model. A significance level of 5\% or less was set for the F test. Tukey's test was applied to compare the means when significant effects were observed for factors with more than two levels. The descriptive statistics and ANOVA were performed using the MEANS and MIXED procedures, respectively, of the Statistical Analysis System (SAS; version 9.2) software.

\section{Results and Discussion}

Of the 6,408 bulls evaluated in 2004 and 2005, 4,030 were classified as suitable for reproduction $(63 \% ; 2,276$ and 1,754 in 2004 and 2005, respectively), 464 were classified as suitable to reproduce naturally $(7 \% ; 237$ and 227 in 2004 and 2005, respectively), 1,605 were classified as temporarily unfit for reproduction $(25.04 \%$; 975 and 630 in 2004 and 2005, respectively), and 309 were excluded from reproduction (4.82\%; 162 and 147 in 2004 and 2005, respectively). These values are far lower than those published by Carrol, Ball and Scott (1963) in Colorado and Vale et al. (1979) in Brazil, who reported that $20 \%$ and $53.34 \%$ of the animals, respectively, were not fit to be used as sires. It is worth noting that the herd that was used in this study consisted of animals that belonged to the company that makes the selection and improvements since birth, which indicates the criteria for genotypic selection and for better general management.

The percentages of the animals excluded, depending on the condition that made them unsuitable for reproduction, are shown in Table 1. It can be observed that most of the excluded bulls suffered from testicular and seminal vesicle pathologies, followed by those suffering from sperm defects and penile alterations. These results 
corroborate those of Vale et al. (1979), who showed that the main causes of low fertility or infertility in bulls were testicular-related alterations, such as testicular degeneration, testicular hypoplasia, and imperfect spermiogenesis.

Table 1

Reasons of excluding young Nelore bulls, which were evaluated by andrological examinations in 2004 and 2005 and bred to be used extensively in a herd improvement program, from reproduction

\begin{tabular}{lccc}
\hline \multirow{2}{*}{ EXCLUSION CATEGORY } & \multicolumn{3}{c}{ EXCLUDED ANIMALS } \\
\cline { 2 - 4 } & $2004 \mathrm{n}(\%)$ & $2005 \mathrm{n}(\%)$ & TOTAL n (\%) \\
\hline Penile disorders & 16 & 5 & $21(6.79)$ \\
Testicular disorders & 59 & 39 & $98(31.70)$ \\
Anterior or posterior limb disorders & 4 & 8 & $12(3.88)$ \\
Epididymal disorders & 0 & 2 & $2(0.65)$ \\
Spermatic cord disorders & 1 & 2 & $3(0.97)$ \\
Spermatic disorders & 21 & 32 & $53(17.15)$ \\
Anal sphincter disorders & 3 & 6 & $9(2.91)$ \\
Foreskin disorders & 2 & 2 & $4(1.29)$ \\
Systemic disorders & 6 & 4 & $10(3.24)$ \\
Seminal vesicle disorders & 50 & 47 & $97(31.39)$ \\
\hline \multicolumn{1}{c}{ TOTAL } & 162 & 147 & 309 \\
\hline
\end{tabular}

Of the 309 animals excluded from reproduction, 98 (accounting for $31.71 \%$ of the excluded and for $1.53 \%$ of the total number of animals) suffered from testicular alterations, such as testicular asymmetry (63/98), small SP for their age (32/98), orchitis (2/98), and hydrocele (1/98). Considering that the analyzed herd is part of a breeding program aiming at selling breeding bulls, animals identified with marked testicular asymmetry during the andrological examination were excluded, as this alteration is suggestive of testicular hypoplasia, even before successive andrological examinations, which are necessary for a definitive diagnosis, are performed. A correct and definitive diagnosis of testicular hypoplasia that is genetic in nature (Vale et al., 1979; Steffen, 1997) is of fundamental importance, especially in the case of partial hypoplasia, to prevent the diffusion of this characteristic to the herd (Ohashi et al., 2018).
Bulls with unilateral (partial or total) or partial bilateral hypoplasia can be fertile, have normal libido, and function normally and are, therefore, difficult to identify in herds. Thus, the confirmation of testicular asymmetry during testicular biometry, especially at puberty, may be an indicator of partial unilateral hypoplasia. The testicles must be symmetrical in terms of size and shape. If they are asymmetric, it has been suggested that the volume difference between them should not be greater than $10 \%$, while the length or width difference between them should not be accentuated. Thus, owing to the genetic origin of the abnormality, animals that have been diagnosed or are suspected to suffer from hypoplasia should be castrated and excluded from reproduction (Vale et al., 1979; Steffen, 1997).

Seminal vesicle alterations were the second most frequent alteration category, as they accounted for $31.39 \%$ of the excluded animals (of these, $64.9 \%$ 
and $35.5 \%$ of bulls had unilateral and bilateral vesiculitis, respectively). These percentages accounted for $0.57 \%$ of animals suffering from vesiculitis in the herd $(97 / 6,408)$; these values are lower than those reported by Ohashi, Sousa, Ribeiro and Vale (1988) $(3.2 \% ; 3 / 80)$ in Nelore bulls, and by Rovay, Barth, Chirini-Trejo and Martinez (2008) in 9-12-month-old taurine cattle $(4.4 \%$; 97/2,207).

In this study, we verified increases in the size, tenderness, and fibrous nodule presence during the rectal palpation and clinical examination of the seminal vesicles. Vesiculitis can be acute or chronic and is caused by bacteria, viruses, chlamydia, fungi, or protozoa. Young bulls are the most susceptible to vesiculitis, mainly owing to the occurrence of homosexual behavior, especially when many animals are concentrated in the same place (Blom \& Christensen, 1965; Bicudo, Siqueira, \& Meira, 2007), which was verified in this study. Additionally, according to Rovay et al. (2008), the reflux of semen and urine into the vesicular gland may occur in young animals, thereby triggering an inflammatory process, which is not necessarily caused by bacteria and could be healed spontaneously.

The next more frequent alterations were sperm changes. Of the 309 animals excluded from reproduction, $53(17.15 \%$ of the excluded and $0.83 \%$ of the total number of animals) were excluded because they had high sperm pathology percentages. Of the verified sperm defects, $58.29 \pm 21.34 \%$ were classified as major defects, $10.14 \pm 12.25 \%$ as minor defects, and $68.43 \pm 24.74 \%$ as total defects. The values are well above those recommended by CBRA (2013) where the ejaculation of bulls should not exceed $30 \%$ of total sperm defects; 10 and $20 \%$ of major and minor defects, respectively, and no more than 5 and $10 \%$ of major and minor individual defects, respectively.
Among the major defects, the predominance of acrosome defects (18.75 $\pm 14.28 \%$ ), narrow head at the base $(9.65 \pm 11.86 \%)$, intermediate piece defect $(8.16 \pm 17.50 \%)$, and strongly folded or curled tail $(5.26 \pm 5.26 \%)$ were verified (Table $2)$. In morphological changes resulting from spermatogenesis for which the manifestation location is the testicle, the semen will present high sperm pathology rates, mainly in terms of spermatozoid head defects and DNA damage, while there may also be high acrosome, intermediate piece, and tail pathology rates, as observed in this study.

Any change that compromises the integrity of the acrosome may result in high fertility reduction, as this change prevents sperm from binding to the zona pellucida. Sperm head alterations are associated with transient or permanent alterations in spermiogenesis, resulting mainly from testicular lesions caused by injury, caloric stress, and genetics. Defects such as a narrow head at the base are closely associated with abnormalities in sperm chromatin condensation. These cells exhibit normal motility and the acrosome may fertilize the oocyte, but embryonic development does not occur due to chromatin abnormalities (Arruda et al., 2015).

All intermediate part alterations interfere with the production of energy (ATP) required for the flagellar beat to occur. Therefore, this alteration is directly related to sperm motility and prevents sperm from reaching the fertilization site. Changes in the tails of spermatozoa occur during sperm maturation, while they pass through the epididymis, where the tails bend after they are formed. This change may be present in degenerative processes of the testicles or in sexual immaturity, as the epididymal environment is altered (Arruda et al., 2015). 
Table 2

Mean and standard deviation of the main sperm pathologies present in extensively bred young Nelore bulls, excluded from reproduction owing to the presence of high sperm pathology rates

\begin{tabular}{ccccc}
\hline Sperm Pathology & Average & Standard Deviation & Total Average & TOTAL Standard Deviation \\
\hline ACR & 18.75 & 14.28 & 3.67 & 9.10 \\
GD & 7.18 & 10.31 & 1.56 & 5.84 \\
SUB & 1.30 & 2.55 & 0.25 & 1.12 \\
CEC & 1.26 & 2.81 & 0.24 & 1.22 \\
ESTB & 9.65 & 11.86 & 1.86 & 5.84 \\
PEQAN & 1.28 & 4.24 & 0.23 & 1.73 \\
POUCH & 2.26 & 5.89 & 0.36 & 2.45 \\
IP & 8.16 & 17.50 & 1.36 & 7.44 \\
CDE & 5.26 & 5.26 & 1.59 & 3.67 \\
DELG & 1.76 & 2.64 & 0.35 & 1.25 \\
CIN & 2.42 & 10.72 & 0.45 & 4.28 \\
AB & 4.68 & 7.05 & 1.16 & 3.82 \\
DM & 58.29 & 21.34 & 11.89 & 23.05 \\
DMEN & 10.14 & 12.25 & 2.37 & 6.49 \\
DT & 68.43 & 24.74 & 14.25 & 27.04 \\
\hline
\end{tabular}

ACR: acrosome defect; GD: distal drop; SUB: underdeveloped; CEC: coiled tail at the head; ESTB: narrow at base; PEQAN: small abnormal head; POUCH: pouch formation; PI: intermediate part defect; CDE: bent and coiled tail; DELG: slender head; CIN: normal isolated head; AB: abaxial; DM: major defects; DMEN: minor defects; DT: total defects.

Among the minor defects observed, distal cytoplasmic droplets $(10.14 \pm 12.25 \%$; Table 2$)$ were more predominant than other defects, also owing to epididymal alterations. Other spermatic defects such as tails with abaxial insertion, normal isolated head, slender head, curled tail, pouch formation, small abnormal head, and underdeveloped head were also observed, but to a lesser extent (Table 2).

The prognosis of the recovery of the fertility rate of animals depends on the origin of the change, whether genetic or environmental. The sexual maturity of 21-month-old Nelore bulls, sold as breeding stock, must by verified by an andrological examination; therefore, if they have high sperm pathology rates, it is recommended to exclude the animals from breeding.

Of the 309 animals excluded from reproduction, $21(6.79 \%$ of the discarded and $0.32 \%$ of the total animals) had some type of penile alteration, such as persistence of the frenulum (16/21) and total or partial penile adhesion $(5 / 21)$. These alterations were not reported by Rabelo (2009) who evaluated the prevalence of penile and foreskin alterations in 12,320 bulls and observed that out of $898(7.29 \%)$ animals, $728(81 \%)$ suffered from acroposthion phimosis, 46 (5.20\%) from penile deviation, 23 $(2.6 \%)$ from gland fibropapilloma, 14 (1.6\%) from preputial abscesses, and $11(1.2 \%)$ from penile fractures.

Perhaps the absence of the aforementioned alterations in this study could be attributed to the fact that the animals tested were young, as older animals are more predisposed to develop alterations such as penile fractures caused, for example, by frustrated mount attempts, and were never used for natural service. It should be noted that the fibropapillomas (10/97) recorded in the present study, were classified as systemic and not as penile alterations. 
During the pre-puberty period, the detachment of the penis from the inner lamina of the foreskin is one of the indicators of the beginning of the reproductive phase of bovine males. This anatomical feature reflects sexual development and is considered as one of the characteristics that define the age at puberty (Hardin, Godfrey, \& Harrison, 1982). The existence of a concentric, adherent persistence between the free part of the penis and the foreskin is common and can last until the first covering occurs, at which point it breaks down due to mechanical tension. The presence of total adhesion can result in the elimination of the animal from reproduction, especially when one is selecting young bulls for the genetic improvement of the herd, as the persistence of penile adhesion in animals after puberty is indicative of slower animals. From that point on, it can be a problem in the selection of animals for breeding.

In addition, a persistent frenulum in bulls aged 11 months or older is considered pathological. As this is a genetic alteration (Carrol et al., 1963), which prevents the protrusion of the penis at the time of cover, surgical correction is not recommended (Chenoweth, Hopkins, Spitzer, \& Larsen, 1993; Nascimento \& Santos, 2011; Steffen, 1997; Van Camp, 1997).

Penile diseases are almost always neglected during the clinical-andrological examination, perhaps owing to the difficulty in exposing the penis. However, as these alterations make copulation difficult, it is important to stress the need to examine the semen carefully during an andrological examination, the purpose of which is the selection of a sire (Ohashi et al., 2018).

Regarding foreskin alterations, only three animals suffered from phimosis and one suffered from stenosis of the preputial ostium (Table 1). According to Rabelo, Vulcani and Cardoso (2012), among the diseases and anomalies affecting the anatomical characteristics of the foreskin, we can highlight chronic preputial prolapse, preputial abscess, preputial diverticulum, persistence of the preputial frenulum, and preputial phimosis. These changes were not recorded in the studied herd. It should be noted that the persistence of the frenulum in this study was classified as a penile alteration.

Regarding the anterior and posterior limb alterations (category 3/Table 1) of the 12 excluded animals, five suffered from hoof lesions, two from limb lesions, two from fractures, two from grooming defects, and one from hygroma. During the andrological examination, the animal should be evaluated by assessing the normality of several systems (respiratory, circulatory, nervous, digestive, locomotor), both while it is resting and while in motion, by paying special attention to its alignment, hooves, and joints. In this sense, the locomotor system deserves special attention owing to its significance in terms of walking in search of food, looking for females in heat, and copulating. It is worth pointing out that pain manifestations are important causes of impotence (Barbosa, Machado, Carneiro, \& Bergamaschi, 2005).

Epididymal and spermatic cord alterations were scarce in the studied herd (Table 1). Regarding category 4 (epididymal alterations), one animal was excluded as it suffered from epididymal tail fibrosis, possibly caused by epididymitis, and one animal was excluded as it suffered from segmental aplasia of the epididymal tail. Both cases can be either uni- or bilateral, almost always evolve into spermatocele, and may result in the development of sperm granulomas (Blom, 1973; Nascimento \& Santos, 2011).

Additionally, spermatic cord alterations were also infrequent (two animals suffered from testicular torsion and one from shortened spermatic cord), as were alterations related to the stenosis of the anal sphincter (nine animals/Table 1).

Table 3 shows the effects of age, testicular biometry characteristics, physical aspects of semen, and morphological aspects of sperm on animals excluded from reproduction and classified into 
different categories. Owing to the low number of animals excluded from reproduction because of epididymal, spermatic cord, anal sphincter, foreskin, and systemic alterations (categories 4, 5, 7, 8, and 9, respectively), these were not evaluated. The effect $(p<0.05)$ of SP and spermatic defects (major, minor, and total) in relation to the types of alterations in the excluded bulls was verified. The SP was smaller in bulls with penile and testicular pathologies than in animals with anterior or posterior limb alterations, sperm alterations, and seminal vesicle alterations (Table 3). Although there were no age differences ( $p>0.05$ ) among the excluded animals, we observed that, animals with penile pathologies were younger (21.3 months old) compared to animals from the other groups, and a trend was observed in the $p$ value $(0.07)$ of this variable.

Table 3

Effect of age, testicular biometry characteristics, physical aspects of the semen, and morphological aspects of the sperm on Nelore bulls classified in different exclusion categories and bred extensively

\begin{tabular}{|c|c|c|c|c|c|}
\hline \multirow{2}{*}{ Variable } & \multicolumn{5}{|c|}{ Exclusion Category } \\
\hline & 1 & 2 & 3 & 6 & 10 \\
\hline & $\mathrm{n}(\%)$ & $\mathrm{n}(\%)$ & $\mathrm{n}(\%)$ & $\mathrm{n}(\%)$ & $\mathrm{n}(\%)$ \\
\hline AGE & $638(13.1)$ & $660(8.4)$ & $654(16.1)$ & $677(10.0)$ & $661(8.5)$ \\
\hline SP & $32.46(1.131)^{\mathrm{ab}}$ & $31.07(0.960)^{\mathrm{b}}$ & $33.86(1.3654)^{\mathrm{a}}$ & $33.81(1.003)^{\mathrm{a}}$ & $33.13(0.968)^{\mathrm{a}}$ \\
\hline CTE & $11.52(0.324)$ & $11.72(0.213)$ & $12.79(0.493)$ & $11.80(0.233)$ & $11.98(0.216)$ \\
\hline LTE & $6.08(0.279)$ & $6.22(0.252)$ & $6.49(0.325)$ & $6.22(0.256)$ & $6.30(0.252)$ \\
\hline CTD & $11.58(0.327)$ & $11.68(0.234)$ & $12.88(0.473)$ & $11.72(0.253)$ & $11.98(0.244)$ \\
\hline LTD & $6.17(0.316)$ & $6.56(0.289)$ & $6.47(0.363)$ & $6.30(0.293)$ & $6.39(0.289)$ \\
\hline TURB & $0.71(0.484)$ & $1.15(0.552)$ & $0.94(0.370)$ & $0.55(0.236)$ & $0.93(0.272)$ \\
\hline MOT & $58.18(11.711)$ & $62.51(13.484)$ & $67.37(8.418)$ & $50.31(4.107)$ & $60.06(4.754)$ \\
\hline VIG & $2.70(0.455)$ & $3.07(0.524)$ & $2.93(0.330)$ & $2.33(0.175)$ & $2.80(0.198)$ \\
\hline $\mathrm{DM}$ & $1.68(3.071)^{\mathrm{b}}$ & $0.16(2.154)^{b}$ & $5.23(3.699)^{b}$ & $53.73(2.422)^{\mathrm{a}}$ & $4.59(2.144)^{b}$ \\
\hline DMEN & $0.17(1.427)^{\mathrm{b}}$ & $0.20(0.873)^{b}$ & $2.63(1.779)^{\mathrm{b}}$ & $9.42(1.039)^{\mathrm{a}}$ & $1.11(0.864)^{\mathrm{b}}$ \\
\hline DT & $1.83(4.240)^{\mathrm{b}}$ & $0.13(3.317)^{\mathrm{b}}$ & $7.77(4.890)^{\mathrm{b}}$ & $64.52(3.571)^{\mathrm{a}}$ & $5.45(3.292)^{\mathrm{b}}$ \\
\hline
\end{tabular}

AGE: age of the bull in days; SP: scrotal circumference $(\mathrm{cm})$; CTE: left testicle length $(\mathrm{cm})$; LTE: left testicle width (cm); CTD: right testicle length $(\mathrm{cm})$; LTD: right testicle width $(\mathrm{cm})$; TURB: sperm wave motion $(1-5)$; MOT: rectilinear progressive sperm motility (\%); VIG: sperm vigor (1-5); DM: major sperm defects (\%); DMEN: minor sperm defects (\%); DT: total sperm defects (\%). Categories: 1: penile alterations; 2: testicular alterations; 3: anterior or posterior limb alterations; 6: spermatic alterations; 10: seminal vesicle alterations. ${ }^{\text {a-d }}$ averages followed by different letters in the same line are statistically different by Student's $t$ test at a $5 \%$ probability level.

Younger animals possibly have smaller SP, which justifies the SP differences between the animals suffering from penile disorders and those suffering from other disorders, as penile disorders such as adhesion can be associated with prepubescent animals, i.e., younger animals.

As expected, there were differences $(p<0.05)$ in the major, minor, and total sperm defects between the animals from group 6, which were excluded owing to sperm alterations (Table 3), and animals belonging to other groups. This demonstrates that even if all other reproductive characteristics are intact, a bull can still be excluded from reproduction for impotentia generandi; additionally, even if the various physical parameters of the semen are in satisfactory levels, the morphological evaluation 
is very important in order to reach a definitive diagnosis.

Although there were no differences $(\mathrm{p}>0.05)$ in terms of the wave motion, motility, and vigor of the sperm, these values were lower in the excluded animals that suffered from sperm alterations (excluded category 6). Sperm motility is usually low $(50.31 \%)$, as is the wave motion and vigor, while, in severe cases the sperm concentration is very low to the point where the animal can suffer from azoospermia. Vale et al. (1979) found that spermiogenesis disorders of congenital or acquired origin (testicular degeneration, delayed sexual maturity, testicular hypoplasia, imperfect spermiogenesis), or sexual immaturity, are the main causes of low fertility or infertility in bulls raised in Brazil.

\section{Conclusions}

The low percentage of animals excluded from reproduction, which was characterized by high reproductive alteration rates in young bulls in the studied herd, indicates the adequacy of the selection program.

Confining the herd for two months and subjecting the animals to their first andrological examination at a younger than usual age, with the objective of selling them, may be responsible for the higher incidence of pathologies related to the seminal vesicles (owing to the homosexual behavior of males) and of penises with high adhesion rates, which is a characteristic of animals that have not yet entered puberty.

\section{Acknowledgments}

We would like to thank $\mathrm{CNPq}$ for awarding us the Scientific Initiation grant, the Agro-pecuária company CFM Ltda, for authorizing the data collection for the study, and Fapemig for the financial support in publishing this study.

\section{References}

Arruda, R. P., Celeghini, E. C. C., Garcia, A. R., Santos, G. C., Leite, T. G., Oliveira, L. Z.,... Rodrigues, M. P. (2015). Morfologia espermática de touros: interpretação e impactos na fertilidade. Revista Brasileira de Reprodução Animal, 39(1), 47-605.

Barbosa, R. T., Machado, R., Carneiro, M. A., \& Bergamaschi, M. (2005). A importância do exame andrológico em bovinos. Circular Técnico, 4l(1), $1-13$.

Bicudo, S. D., Siqueira, J. B., \& Meira, C. (2007). Patologias do sistema reprodutor de touros. Biológico, 69(2), 43-48.

Blom, E. (1973). The ultrastructure of some characteristic sperm deffects and a proposal for a new classification of the bull spermiogram. Nordisk Veterinaer Medicin, 25(7), 383-391.

Blom, E. (1983). Pathological conditions in the genital organs and in the semen as grounds for rejection of breeding bulls for import and export to or from Denmark. Nordisk Veterinaer Medicin, 35(3), 105130.

Blom, E., Christensen, N. O. (1965). Seminal vesiculitis in the bull caused by Corynebacterium pyogenes, Nordisk Veterinaer Medicin, 17, 435-445.

Carrol, E. J., Ball, L., \& Scott, J. A. (1963). Breeding soundness in bulls - A summary of 10,940 examinations. Journal American Veterinary Medicine Association, 142(10), 1105-1111.

Chenoweth, P. J., Hopkins, F. M., Spitzer, J. C., \& Larsen, R. E. (1993). Guidelines for using the bull breeding soundness evaluation form. Theriogenology Handbook, B-10(7), 1-16.

Colégio Brasileiro de Reprodução Animal (2013). Manual para exame andrológico e avaliação de sêmen animal ( $3 \mathrm{a}$ ed.). Belo Horizonte: CBRA.

Guimarães, J. D. (1997). Avaliação andrológica e estudos quantitativos e qualitativos da espermatogênese de touros mestiços F1 Holandês x Zebu e Red Angus $x$ Zebu. Tese de doutorado, Escola de Veterinária da Universidade Federal de Minas Gerais, Belo Horizonte, MG, Brasil.

Hancoch,J.L.(1956). Themorphologyofboarspermatozoa. Journal of the Royal Microscopical Society, 76(3), 84-97. doi.org/10.1111/j.1365-2818.1956.tb00443.x

Hardin, D. R., Godfrey, R. W., \& Harrison, L. M. (1982). Partial characterization of the puberal development in Brahman bull. Journal of Animal Science, 55(1), 20. 
Krause, D. (1993). Sistema reprodutor masculino. In D. Gerrit, G. Hans-Dieter, \& S. Matthaeus (Eds.), Rosenberger-exame clínico dos bovinos (pp. 24226). Rio de Janeiro: Guanabara Koogan.

Nascimento, E. F., \& Santos, R. L. (2011). Patologia da reprodução dos animais domésticos. Rio de Janeiro, RJ: Guanabara Koogan.

Ohashi, O. M., Santos, S. S. D., Almeida, N. N. C., Silva, T. V. G., Cordeiro, M. S. \& Rolim, M. S., S. T., Fo . (2018). Patologias clínicas reprodutivas e resultados de tratamentos. Anais da Reunião Anual da Associação Brasileira de Andrologia Animal, Campo Grande, MS, Brasil, 3.

Ohashi, O. M., Sousa, J. S., Ribeiro, H. F. L., \& Vale, W. G. (1988). Distúrbios reprodutivos em touros Bos indicus, Bos taurus e mestiços, criados em condições de clima Amazônico. Pesquisa Veterinária Brasileira, 8(1/2), 31-35.

Rabelo, R. E., (2009). Desvio traumático de pênis em bovinos: aspectos epidemiológicos, morfofuncionais e tratamento cirúrgico. Tese de doutorado, Universidade Federal de Goiás, Goiânia, GO, Brasil.
Rabelo, R. E., Vulcani, V. A. S., \& Cardoso, L. D. (2012). Aspectos anatômicos e sua relação com as enfermidades do prepúcio e pênis no Touro. Revista Científica Eletrônica de Medicina Veterinária, 18(1), 1-24.

Rovay, H., Barth, A. D., Chirino-Trejo, M., \& Martínez, M. F. (2008). Update on treatment of vesiculitis in bulls. Theriogenology, 70(3), 495-503. doi: 10.1016/j.theriogenology.2008.05.002

Steffen, D. (1997). Genetic causes of bull infertility. The Veterinary Clinics of North America: Food Animal Practice, 13(2), 243-253. doi: 10.1016/s07490720(15)30338-8

Vale, V. R., F' ., Pinto, P. A., Fonseca, J., \& Soares, L. C. O. V. (1979). Patologia do sêmen; diagnóstico andrológico e classificação de Bos taurus e Bos indicus quanto à fertilidade para uso como reprodutores em condições de Brasil - de um estudo de 1088 touros. São Paulo, SP: Dow Química.

Van Camp, S. D. (1997). Common causes of Infertility in the bull. The Veterinary Clinics of North America: Food Animal Practice, 13(2), 203-232. doi: 10.1016/ s0749-0720(15)30336-4 
